\title{
Renata Aleksandrowicz, Książka w życiu seniorów na początku XXI wieku, Warszawa 2020, Wydawnictwo SBP
}

Książka w życiu seniorów na poczq̨tku XXI wieku, autorstwa Renaty Aleksandrowicz ${ }^{1}$ to publikacja wydana, w ramach serii Nauka

- Dydaktyka - Praktyka² przez Wydawnictwo Naukowe i Edukacyjne

1 Dr Renata Aleksandrowicz jest pracownikiem naukowym Instytutu Informacji Naukowej i Bibliotekoznawstwa Uniwersytetu Wrocławskiego. Wśród jej zainteresowań naukowo - badawczych należy wymienić badania czytelnictwa w Polsce i na świecie, zachowania i kulturę czytelniczą ludzi starszych, jako czytelników książek i użytkowników informacji, czytelnika specjalnego w bibliotece oraz biblioterapię w teorii i praktyce. R. Aleksandrowicz jest autorką kilkudziesięciu artykułów i współredaktorką książek poświęconych powyższej tematyce. Prowadzi zajęcia z zakresu czytelnictwa współczesnego, biblioterapii, komunikacji społecznej i technik wywierania wpływu na rynku książki. Jedne z ważniejszych publikacji autorki: Promocja książki na przykładzie Stiftung Lesen, Działalność Herzog August Bibliothek w zakresie promocji książki i czytelnictwa, Obraz czytelnika-seniora w literaturze gerontologicznej i badaniach czytelniczych, Maria Dembowska: $w$ kręgu bibliografii, bibliotekarstwa i informacji naukowej, Książka w życiu i kulturze Polaków: 50 lat serii $Z$ badań nad czytelnictwem, „Trzeci wiek” $w$ społeczeństwie informacyjnym, Senior w wielkim mieście: kontakt z książkq i bibliotekq słuchaczy Uniwersytetu Trzeciego Wieku, Okoliczności lekturowego dzieciństwa współczesnych seniorów na przykładzie wspomnień słuchaczy Uniwersytetu Trzeciego Wieku.

2 Seria Nauka - Dydaktyka - Praktyka, wydawana jest od 1993 roku, przez Wydawnictwo Naukowe i Edukacyjne SBP, we współpracy z Wydziałem Dziennikarstwa, Informacji i Bibliologii Uniwersytetu Warszawskiego. Ma ona charakter naukowy. Poświęcona jest analizie czytelnictwa, działaniom popularyzacyjnym, upowszechnianiu wyników badań związanych z bibliotekoznawstwem, bibliologią, informacją naukową czy też dyskusji nad ówczesnym stanem książki, bibliotek i kultury 
Martyna Lewandowska - Renata Aleksandrowicz, Książka...

$\mathrm{SBP}^{3}$, przy współpracy z Instytutem Informacji Naukowej i Bibliotekoznawstwa Uniwersytetu Wrocławskiego. Tematyka książki skupia się wokół kultury i komunikacji czytelniczej seniorów wielkomiejskich, ich wyborów lektur oraz zagadnień związanych z obcowaniem z książką w dobie technologii komputerowej. Autorka podjęła próbę rozpoznania zachowań i aktywności lekturowych, ich okoliczności, wskazujących na charakterystyczne oraz zindywidualizowane doświadczenia czytelnicze aktywnych seniorów. Przez okres trzech lat (2008-2010) jako jedna z uczestniczek i osób prowadzących zajęcia, badała preferencje, style, bariery oraz źródła informacji i dostępu do książek 240 słuchaczy Uniwersytetu Trzeciego Wieku, działającego przy Uniwersytecie Wrocławskim. Renata Aleksandrowicz badając rolę i miejsce książki w przeszłości osób starszych, od czasów ich dzieciństwa, aż do starości, próbowała odpowiedzieć na pytanie, czy doświadczenia z dzieciństwa i młodości, wpływają na charakter zachowań lekturowych w trzecim wieku. Dla pełnego przeanalizowania interesującego ją zagadnienia, autorka zebrała dane dotyczące postrzegania, definiowania i sposobu spędzania czasu wolnego aktywnych osób w wieku 60+. Ponadto doszukiwała się pewnych cech charakterystycznych $w$ ich stosunku do komputera i technologii.

Lektura ma przejrzystą i przemyślaną strukturę. Składa się z dwóch wyraźnie wyodrębnionych części, a każda z nich z rozdziałów i podroz-

słowa. Autorami tekstów są specjaliści oraz uznani i cenieni przedstawiciele nauki o książce i informacji. W ramach tego cyklu ukazało się ponad 195 tytułów, w tym omawiana praca Renaty Aleksandrowicz (jako 196 numer serii). Źródło: Wydawnictwo Naukowe i Edukacyjne SBP, http://www.sbp.pl/wydawnictwa, [online, dostęp w dniu 20.02.2021].

3 Wydawnictwo Naukowe i Edukacyjne SBP - to największa oficyna wydawnicza środowiska bibliotekarskiego w Polsce. Jego tradycja liczy ponad 100 lat. Publikuje monografie naukowe, prace zbiorowe, słowniki, podręczniki, prace o charakterze popularno - naukowym, poradniki, czasopisma naukowe i fachowe dotyczące bibliologii, bibliotekoznawstwa, informacji naukowej itd. Treści wydawane są głównie w seriach, należy tu wymienić: Nauka - Dydaktyka - Praktyka, Literatura dla dzieci i młodzieży. Studia, Biblioteki - Dzieci - Młodzież, Propozycje i materiały, FO-KA, Biblioteczka poradnika bibliotekarza, Bibliotekarze polscy we wspomnieniach współczesnych. Źródło: Tamże. 
działów. Całość opatrzona jest szczegółowym wstępem oraz zakończeniem. To właśnie we wstępie, autorka definiuje pojęcia, których dotyczy rozprawa, a którymi posługuje się w dalszej jej części - starość, proces starzenia, aktywność człowieka, kultura czytelnicza, zachowania czytelnicze czy też zachowania lekturowe. Wymienia ona także klasyfikacje starości, podkreślając wielość i rozbieżność ich periodyzacji w literaturze, ostatecznie przyjmując typologię Światowej Organizacji Zdrowia, która wyodrębnia u osób po 60 roku życia, wczesną starość, późną starość oraz długowieczność. Aleksandrowicz wielokrotnie posługuje się w tekście także określeniami tj. „młodzi starzy” (young-old), „starzy-starzy” (old-old) oraz „długowieczni” (longlife), których użyto w Raporcie na tematy sytuacji osób starszych w Polsce ${ }^{4}$, opublikowanym w 2012 roku. Jako przedmiot badań wskazuje najstarszych członków społeczeństwa - seniorów - słuchaczy UTW, zaś za cel przyjmuje poznanie, opisanie i typologię ich zachowań lekturowych. Autorka sformułowała dziewięć pytań badawczych, które wyznaczały zakres procesu badania i zbierania danych. Jak już wspomniano, we wstępie przeprowadzono rzetelny przegląd badań polskich, jak i zagranicznych dotyczących czytelnictwa, aktywności seniorów oraz ich obcowania z książką.

W części pierwszej, teoretycznej, autorka wprowadza czytelnika w problematykę starości na łamach trzech następujących rozdziałów: Wprowadzenie w problematykę starzenia się i starości, Seniorzy w społeczeństwie wiedzy, Czas wolny seniorów. Opisuje ona proces starzenia się społeczeństwa, jego psychospołeczne determinanty, konsekwencje oraz teorie stylów życia seniorów, mianowicie teorie adaptacji do starości - teorie aktywności i wycofania się. Wymienia także teorię konstruktywnej starości, starości z wyboru, stylu życia, przepływu i teorię kompetencyjną. Aleksandrowicz, za Małgorzatą i Jerzym Halickimi, prezentuje klasyfikację aktywności seniorów przechodząc płynnie do ich funkcjonowania w społeczeństwie wiedzy, skupiając się na istniejących ograniczeniach i zagrożeniach, w tym informacyjnych i techno-

$4 \quad$ Raporto sytuacji osób starszych w Polsce, http://senior.gov.pl/source/raport_osoby\%20 starsze.pdf, [online, dostęp w dniu 20.02.2021]. 
Martyna Lewandowska - Renata Aleksandrowicz, Książka...

logicznych. Seniorzy zmagają się z dyskryminacją, samowykluczaniem się, problemami z tożsamością, brakiem stabilności i więzi ze środowiskiem zewnętrznym. Nierówności związane z erą nowych technologii poszerzyły powyższy katalog i uwidoczniły się w zdecydowanej większości w grupie old-old, która nie obcowała z komputerem, nawet $\mathrm{w}$ pracy zawodowej. Potwierdziły to wyniki raportu dotyczącego kompetencji medialnych Polaków, w którym odniesiono się także do seniorów5 . Jako główną barierę wskazano wówczas aspekt psychologiczny, tzw. „lęk komputerowy”. Na podstawie przeglądu literatury, autorka zauważa również, iż starszym brak motywacji i potrzeby korzystania z technologii. Powołuje się na najnowsze wyniki badań, z których wynika, iż wciąż najbardziej wykluczeni sieciowo są seniorzy w wieku 65+. Podkreśla ona jednak optymistycznie rolę andragogiki, gerontologii oraz podejścia „lifelong learning”, a więc edukacji całożyciowej w wyrównywaniu nierówności, barier, trudności i braków edukacyjnych, mentalnych i psychicznych seniorów. Jednocześnie edukacja ta spełnia funkcję terapeutyczną, kompensacyjną, integracyjną oraz adaptacyjną.

W rozdziale trzecim, kończącym rozważania teoretyczne, odnajdujemy specyfikę i postawy osób starszych wobec czasu wolnego oraz sposoby jego spędzania. $\mathrm{W}$ tym fragmencie również pojawiają się odwołania do wyników badań w tym zakresie. Aleksandrowicz po ich wnikliwej analizie wymienia charakterystyczne dla osób starszych, grupy zjawisk, takie jak np. czas dla siebie, czas przymusowo wolny, czas pozornie wolny oraz niezorganizowany i niekontrolowany. Wśród dominujących form spędzania czasu wskazuje oglądanie telewizji, słuchanie radia, aktywność fizyczną, spacery, pracę w ogródku, spotkania towarzyskie czy też czytanie książek. Zauważa przy tym, iż na aktywność seniorów w czasie wolnym i jej organizację, wpływają możliwości, motywacja uczestnictwa w kulturze i życiu społecznym, ale także środo-

$5 \quad$ Korzystanie z mediów a podziały społeczne. Kompetencje medialne Polaków w ujeciu relacyjnym, https://ngoteka.pl/bitstream/handle/item/215/korzystanie $\% 20$ z\%20mediow\%20a\%20podzialy\%20spoleczne.pdf?sequence=3, [online, dostęp w dniu 20.02.2021]. 
wisko zamieszkania (wieś, miasto, duże miasto). W podsumowaniu tej części pracy, autorka zawarła stwierdzenie, iż obecni seniorzy, to osoby urodzone w czasach wojny lub okupacji, o różnych doświadczeniach życiowych, które determinują sposób przeżywania i spędzania starości. Nie charakteryzuje ich stagnacja, opór czy niechęć do wszelkich przejawów aktywności. Badani przedstawiciele trzeciego wieku chcą się edukować, uczestniczyć w życiu społecznym, kulturalnym a nawet technologicznym.

Druga część pracy oparta jest na badaniach empirycznych Renaty Aleksandrowicz przeprowadzonych wśród słuchaczy Uniwersytetu Trzeciego Wieku przy Uniwersytecie Wrocławskim. Jest to, jak wskazuje sama autorka, próba wieloaspektowej analizy zachowań lekturowych wielkomiejskich, wrocławskich seniorów, członków wskazanej placówki. Wyodrębniono w niej pięć rozdziałów, które kolejno uszczegóławiają wyniki badań w konkretnych obszarach. Są to Metodologiczne podstawy badań własnych, Życie pozalekturowe, czyli aktywność w czasie wolnym, Życie około lekturowe, czyli uczestnictwo w kulturze pisma, Życie w kręgu książki, Typy lektury aktywnych seniorów. Ta część jest zdecydowanie dłuższa, co uzasadnia cel powstania niniejszej rozprawy.

Rozdział pierwszy jest swoistym wprowadzeniem metodologicznym, w którym szczegółowo przestawiono zastosowane metody badawcze z uzasadnieniem ich wyboru, organizację i przebieg badań oraz dobór i charakterystykę badanej grupy. Autorka argumentuje dobór metod i technik zbierania danych tj. sondażu diagnostycznego, wywiadu kwestionariuszowego oraz obserwacji uczestniczącej, próbą dokonania analizy zachowań lekturowych jako zjawiska społecznego, a jednocześnie indywidualnego i priorytetowego potraktowania respondentów. Istotnym jest fakt, iż wyodrębniła ona zmienne, wyznaczające strukturę, kolejność i podział tekstu, są to: wykształcenie, tradycje rodzinne, środowisko, aspiracje, dostępność do książki, ale także indywidualne rysy charakteru, sposób wartościowania oraz osobiste doświadczenia. Autorka przeprowadziła 211 wywiadów, z czego przeanalizowała 194 rozmowy, z 164 kobietami i 30 mężczyznami. Wśród badanych domino- 
Martyna Lewandowska - Renata Aleksandrowicz, Książka...

wali seniorzy w wieku 60-70 lat, co trzeci znajdował się w przedziale 70-80 lat a co dziesiąty miał powyżej 80 . Każdy z nich w przeszłości plasował się w grupie zawodowej tzw. specjalistów, przedstawicieli władz publicznych i wyższych urzędników. Zatem respondenci, jak podkreśla sama autorka, reprezentowali grupę inteligencji wielkomiejskiej.

Rozdział drugi to opis kontekstu pozalekturowego, a więc stosunku do czasu wolnego i sposobów jego spędzania. Autorka zwraca również uwagę na znaczenie książki w codziennym funkcjonowaniu osób starszych. Pod względem postrzegania wolnego czasu, wyodrębniła ona dwie wyraźne grupy: „cieszących się wolnością” oraz „zabieganych aktywnych”. Wskazuje także na „nowicjuszy wolnego czasu”, których odsetek występowania był jednak zdecydowanie mniejszy. Przedstawiła sposoby spędzania czasu wolnego wrocławskich słuchaczy UTW. W zdecydowanej większości dominowała wśród nich aktywność fizyczna, książka, realizacja zainteresowań, instytucje kultury, kontakty międzyludzkie, a na końcu uplasowały się działalność społeczna, brak wolnego czasu oraz aktywność religijna. Aleksandrowicz kolejno opisuje wskazane rodzaje czynności, uzupełniając je wypowiedziami respondentów. Konkludując podkreśla, iż katalog i częstotliwość aktywności seniorów ewaluowały lub zanikały wraz z wiekiem ze względu na stan zdrowia i sprawność fizyczną, ale zależały one także od pory roku (np. praca w ogrodzie wiosną i latem).

W rozdziale trzecim R. Aleksandrowicz scharakteryzowała seniorów jako uczestników kultury pisma, a więc jako odbiorców prasy i użytkowników nowych technologii (komputera i Internetu). Autorka bardzo szczegółowo określiła intensywność czytania prasy, dokonała spisu najchętniej czytanych pozycji wraz z uzasadnieniem oraz starała się doszukiwać przyczyn tych wyborów. Wyróżniła na podstawie doboru prasy i częstotliwości sięgania po nią następujące nastawienia: „przeglądających kompilatorów” oraz „świadomych kontynuatorów”. Wskazała najczęściej wymieniane przez osoby 60+ tytuły. Były to „Polityka”, „Wprost”, „Newsweek”, „Angora”, „Gość Niedzielny”, „Tele Tydzień” i „Życie na gorąco" (to tylko 7 z 25 umieszczonych w wykazie). Autorka pogrupowała 
je na czasopisma opinii, kobiece i pozostałe. Następnie opisała respondentów jako odbiorców i użytkowników nowinek technologicznych. Dokonała ich klasyfikacji wraz z opisem, a mianowicie wyodrębniła grupę użytkowników, jak i nieużytkowników. Ci pierwsi najczęściej korzystali z komputera i Internetu w celu wyszukiwania informacji, komunikacji, pisania tekstów czy grania w gry. Drudzy zaś - nieużytkownicy - w swoim obrębie również byli podzieleni, na chętnych podjęcia w przyszłości aktywności technologicznej i tych, którzy zdecydowanie tego odmawiali $\mathrm{z}$ braku potrzeby, chęci i motywacji nabycia nowych kompetencji. Podsumowanie tej części stanowi konkluzja, iż decyzje seniorów były w znacznej większości samodzielne i dobrowolne.

Rozdział czwarty zawiera analizę całości zachowań, jakie składają się według autorki na praktyki lekturowe seniorów. Wyodrębniono w nim pięć podrozdziałów. Umieszczono w nich refleksje uczestników badania na temat swojego dzieciństwa oraz miejsca i roli książki w latach młodzieńczych. Autorka doszukiwała się cech wspólnych u respondentów, które kształtowały zindywidualizowany charakter kultury czytelniczej w wieku senioralnym. Należy tu wymienić dostępność książek, zasięg oddziaływania książki, posiadanie księgozbioru domowego, pamięć czytelniczą oraz zestawienie najchętniej czytanych książek, autorów i typów literatury. Na podstawie zgromadzonego materiału, wskazano źródła informacji o nowej, ciekawej lub potrzebnej książce. Były to środki przekazu tj. prasa, radio, telewizja, znajomi - koledzy i koleżanki, księgarnie, biblioteki, przynależność do klubu książki, rekomendacje rodziny oraz inne. Jako główne bariery w dostępie do książek, seniorzy podawali trudności natury finansowej oraz zdrowotnej (problemy ze wzrokiem, kręgosłupem, zmęczenie, brak koncentracji itd.), choć zdecydowana większość podkreślała brak barier lub możliwość ich pokonania. Zatem chęć pielęgnowania i kontynuacji praktyki lekturowej mobilizowała seniorów do zdobywania informacji o nowościach i bestsellerach oraz przezwyciężania swoich trosk i przeszkód. W tym samym rozdziale Aleksandrowicz dokonała typologii aktywności lekturowej przed i na emeryturze. Rozróżniła ona czytelników najbardziej 
Martyna Lewandowska - Renata Aleksandrowicz, Książka...

oddanych lekturze w młodości, czytających intensywnie w wieku średnim, czytających najintensywniej na emeryturze, czytających ze zmienną aktywnością w ciągu całego życia oraz stabilnych tj. czytających systematycznie w ciągu całego życia. Charakteryzuje ona wyżej wskazane tendencje a także podaje intensywność czytania w skali roku (od 1-2 książek do ponad 36 woluminów) oraz częstotliwość (codziennie, co drugi dzień, 1-2 w tygodniu itd.) z uwzględnieniem przyczyn takiego stanu rzeczy. Badani seniorzy niezależnie od skali swoich zachowań lekturowych, czerpali przyjemność z czytania i obcowania z książką. Wynikało to także z opisywanych przez autorkę przeszłościowych przyzwyczajeń, ale i z otoczenia tj. posiadanego w domu własnego księgozbioru, rozmów o przeczytanych pozycjach, korzystania z biblioteki (w tym jej oferty kulturalnej i popularyzacyjnej), jak również pamięci lektury. Przez pamięć lektury autorka rozumie nawyki i wybory lekturowe z dzieciństwa i czasów młodości, emocje oraz refleksje związane z daną książką, czy samym procesem czytania. Osoby w wieku 60+ często na emeryturze wracały do pozycji z dzieciństwa. Głównymi okolicznościami towarzyszącymi temu zjawisku były powroty relaksowo-terapeutyczne, medialne, „konfrontacyjno-porównawcze” oraz inne. Także i w tym podrozdziale, autorka wskazała najpopularniejsze książki spośród 465 tytułów podanych przez respondentów oraz opracowała ich typologię. Największy udział procentowy uwidocznił się przy literaturze faktu, obyczajowo-romansowej, beletrystycznej i historycznej. Najmniejszy zaś odsetek uzyskała fantastyka, pozycje dziecięco-młodzieżowe oraz eseistyka i publicystyka (jako jedna kategoria). Znalazło to odzwierciedlenie w nazwiskach autorów i tytułach, jakie w większości podawali słuchacze UTW. Aleksandrowicz kończy ten najdłuższy rozdział refleksją, iż seniorów cechuje znaczna umiejętność porządkowania doświadczeń lekturowych oraz opisywania ze szczegółami przeczytanych książek a także towarzyszących im przy tym odczuć. Świadczy to zatem o ich wysokich kompetencjach czytelniczych, jak również o szczególnej postawie charakteryzującej się docenianiem słowa drukowanego i obcowaniem z książką. 
Ostatni rozdział - piąty, jest podsumowaniem wcześniejszych rozważaniach. Wyłania się z niego obraz seniorów jako odbiorców lektury. Jest to analiza jakościowa roli książek w życiu seniora, próba klasyfikacji podejścia do książki oraz elementów kształtujących nastawienie do nich. Autorka w tym rozdziale zwraca szczególną uwagę na znaczenie lektury w życiu seniora. Wskazuje na funkcje emotywne (bardzo szeroko rozumiane, zawierające 6 podkategorii: emocjonalne, rozrywkowe, integracyjne, terapeutyczne, estetyczne i prestiżowe), informacyjno-poznawcze, motywacyjno-kształcące, filozoficzno-refleksyjne oraz inne. Następstwem takiego podziału funkcji była podjęta przez Aleksandrowicz, próba typologii seniorów jako odbiorców książki. Jak sama wskazała, nie wyczerpuje ona tym podziałem wszystkich możliwości, gdyż kierowała się głównie opisem kierunków patrzenia i myślenia o książkach, wskazanymi tendencjami i nastawieniami do lektury oraz jej miejscem w życiu starszych. Wyodrębniła ona zatem 9 typów: tradycjonaliści, konsumenci książek popularnych, obserwatorzy świata i rzeczywistości, eklektycy, koneserzy, poszukujący sensu życia, odbiorcy wiedzy i użytkownicy informacji, typy mieszane oraz inni, trudni do zakwalifikowania, które szczegółowo opisała na kartach omawianej książki. Seniorzy dokonywali głównie wyboru współczesnych publikacji, poddając się mechanizmom reklamy i promocji. Jednak ich swoistą i charakterystyczną cechą była potrzeba sentymentalnego powrotu do przeszłości, książek z lat dzieciństwa, kanonu lektur czy też klasyki zarówno polskiej, jak i światowej.

Warto w tym miejscu podkreślić, iż uzyskane wyniki nie mogą zostać poddane generalizacji, co zauważa także sama autorka, gdyż słuchacze wrocławskiego UTW stanowili charakterystyczną grupę odbiorców książek, nazwaną przez nią tradycyjną inteligencją wielkomiejską. Byli to ludzie wykształceni, aktywni na emeryturze umysłowo i fizycznie, posiadający wyrobione już w latach dzieciństwa nawyki czytelnicze, dla których książka stawiana była na jednym z pierwszych miejsc, zarówno, jako przedmiot, jak i sposób spędzania czasu wolnego. Nie każdy więc członek społeczeństwa w wieku 60+ podzielałby wskazania i refleksje 
Martyna Lewandowska - Renata Aleksandrowicz, Książka...

badanych, ze względu na przeszłość, wykształcenie czy chociażby nawyki, wyznawane wartości i podejmowane aktywności na emeryturze.

Publikacja Renaty Aleksandrowicz pt. Książka w życiu seniorów na początku XXI wieku, podejmuje ważną współcześnie tematykę z powodu wciąż postępującego procesu starzenia się społeczeństwa. Autorka dzieląc książkę na dwie części, wyodrębniła treści teoretyczne i badawcze. Zestawiła naukowe teorie oraz funkcjonujące w społeczeństwie stereotypy z wynikami badań własnych, które przeprowadziła wśród wrocławskich słuchaczy Uniwersytetu Trzeciego Wieku. Teoretyczny wstęp przygotował czytelnika do odbioru, samodzielnej próby analizy, ale i refleksji nad odpowiedziami respondentów. Analiza jakościowa i ilościowa, wykresy, diagramy i tabele prezentujące konkretne, ale i najistotniejsze treści, hasła oraz zestawienia procentowe pozwoliły na wydobycie szczegółów, które jasno obrazowały tendencje, wybory seniorów czy ujawniające się pewne kategorie zachowań i postaw. Wypowiedzi respondentów jako konkretne przykłady, potwierdzające słowa autorki, wzmagały odczucie realności tych treści oraz swoistego prowadzenia dialogu $\mathrm{z}$ badanymi, wczuwania się $\mathrm{w}$ ich słowa i towarzyszące wypowiedziom emocje.

Podjęta analiza zebranego materiału badawczego, zdaje się wyczerpywać możliwość interpretacji, gdyż autorka dokonała jej wielostronnie i wieloaspektowo. Zaczynając od zachowań czytelniczych z przeszłości, starała się odnaleźć cechy wspólne, poglądy i zachowania dotyczące spędzania czasu wolnego, stosunku i częstotliwości korzystania z prasy, książki aż po próbę wyodrębnienia konkretnych tytułów i autorów, po które sięgali seniorzy. Autorka dokonała analizy i syntezy zgromadzonych wypowiedzi, które pozwoliły na dokonanie klasyfikacji seniorów, ich wyborów czytelniczych oraz stosunku do lektury.

Książka opisuje rzeczywistość zastaną w latach 2008-2010. Autorka nie podaje przyczyny, nie wyjaśnia czytelnikowi powodów publikacji książki, aż dziesięć lat po zakończeniu badań. Zawiera zarówno ogólnopolskie i zagraniczne wyniki badań z tamtego okresu, jak i współczesne, najnowsze teorie i hipotezy. Odwołuje się do publikacji będą- 
cych podstawą, kanonem w dziedzinie bibliologii, bibliotekoznawstwa czy informacji naukowej, ale i do nowych, aktualnych pozycji, w tym podręczników poruszających omawianą tematykę. Warto zaznaczyć, iż recenzowana książka posiada bogatą bibliografię z zakresu wspomnianych wyżej dziedzin, jak również andragogiki czy gerontologii. Czytelnik zostaje odesłany do lektur polskich, jak i zagranicznych oraz badań dotyczących procesu starzenia się i adaptacji do starości z ostatnich dwudziestu lat.

Autorka w zakończeniu zauważa, iż publikacja nie wyczerpuje w pełni poruszanego przez nią tematu i wskazuje, iż warto byłoby udokumentować lekturowe wspomnienia seniorów, które świadczyłyby o świadomości lektury a podkreślałyby rolę języka literackiego, jako nośnika systemu znaków i symboli. Dodaje również, że cenne byłoby przeprowadzenie wywiadów biograficznych, ukazujących historię życia osób starszych, jako podstawę do analizy zachowań lekturowych, jako zjawisko społeczne. Do tych refleksji, po wnikliwym i krytycznym przeanalizowaniu treści, należy dodać, iż warto byłoby zastanowić się nad przeprowadzeniem badań w czasach obecnych, a więc w drugiej dekadzie XXI wieku. Zdecydowanie bardziej uwidacznia się bowiem współcześnie dominacja technologii, mediów społecznościowych i cyfryzacji każdej ze sfer funkcjonowania. Wyniki tychże badań byłyby nie tylko źródłem rzetelnych informacji dla współczesnych naukowców i zainteresowanych tą tematyką, ale również podstawą do projektowania działań popularyzujących czytelnictwo wśród tej grupy odbiorców. Ponadto można by wówczas przeprowadzić analizę porównawczą uzyskanych wniosków.

Podsumowując, książka Renaty Aleksandrowicz dostarcza szczegółowych informacji o charakterystycznych zachowaniach lekturowych wrocławskich słuchaczy Uniwersytetu Trzeciego Wieku, a także obieranych przez nich kierunkach i tendencjach czytelniczych. Opisuje zatem wyczerpująco upodobania lekturowe i istotę książki w życiu tej konkretnej grupy najstarszego pokolenia, a jednocześnie jest źródłem wiedzy teoretycznej o starości i procesach starzenia seniorów. 